\title{
Species composition and inshore migration of the tropical eels Anguilla spp. recruiting to the estuary of the Poigar River, Sulawesi Island
}

\author{
Takaomi Arai ${ }^{1, *}$, Jun Aoyama ${ }^{1}$, Daniel Limbong ${ }^{2}$, Katsumi Tsukamoto ${ }^{1}$ \\ 'Ocean Research Institute, The University of Tokyo, Minamidai, Nakano, Tokyo 164-8639, Japan \\ ${ }^{2}$ Faculty of Fisheries and Marine Science, Sam Ratulangi University, Manado 95115, Indonesia
}

\begin{abstract}
In order to determine the species composition and inshore migration of the tropical eels Anguilla spp. migrating to an Indonesian river, we collected 21633 glass eels at the mouth of the Poigar River, north Sulawesi Island, throughout 1997, and subjected these samples to both morphological examination and polymerase chain reactionrestriction fragment length polymorphism (PCR-RFLP) analysis. Three species, Anguilla celebesensis, A. marmorata and $A$. bicolor pacifica, were found throughout the season in fluctuating abundance, while the previously recorded $A$. borneensis was not recognized in the study. A. celebesensis constituted a dominant $88.3 \%$ of all glass eels migrating to the Poigar River in 1997, and was seen throughout most of the year, with a peak in May and June. A. marmorata (11.3\%) was also seen throughout most of the year, with peak occurrence in June. A. bicolor pacifica $(0.4 \%)$ occurred only in January, March, April, October and December.
\end{abstract}

KEY WORDS: Eel - Glass eel - Tropical Anguilla spp. $\cdot$ Mitochondrial DNA - Species identification - Species composition . Inshore migration

Considerable knowledge has been accumulated on the inshore migration and early life history of juveniles of numerous temperate anguillid species, such as Anguilla japonica (Matsui 1952, 1972, Tzeng 1985, Tsukamoto 1992, Cheng \& Tzeng 1996, Arai et al. 1997), A. anguilla (Deelder 1958, Tesch 1971, Gandolfi et al. 1984, Lecomte-Finiger 1992), A. australis and $A$. dieffenbachi (Jellyman 1977, 1979, Sloane 1984) and A. rostrata (Sorensen 1986, Tongiorgi et al. 1986, Martin 1995, Wang \& Tzeng 1998). These reports have revealed the species composition and migration timing of juveniles, as well as environmental factors affecting

\footnotetext{
•E-mail: arait@ori.u-tokyo.ac.jp
}

the onset of juvenile migration, such as temperature, salinity, tidal cycles and moon phase. In addition, spawning area, birth date, larval age and growth, timing of metamorphosis and age at recruitment to the coastal waters have also been revealed.

However, knowledge of the inshore migration of tropical species is rudimentary compared to that on temperate anguillid species (Tabeta et al. 1976a, Budimawan 1997, Arai et al. 1999a,b). Furthermore, in tropical areas some anguillid species inhabit sympatrically, and thus their exact species identification is difficult because intra-species variation of the morphological key characters overlap considerably between species (Tabeta 1976b, Aoyama 1998). For this reason, species identification and composition have not been well established in the tropical species.

We collected glass eel samples over the course of $1 \mathrm{yr}$ from the mouth of the Poigar River, north Sulawesi Island, Indonesia, where Ege (1939) once described Anguilla ancestralis as the ancestral eel for Anguilla spp., and Castle \& Williamson (1974) established the synonym of $A$. celebesensis thereafter. In order to establish a basic foundation for ecological study in tropical eels, we examined the species composition of tropical anguillid eel juveniles by species identification based on their morphological characteristics and mitochondrial DNA (mtDNA).

Materials and methods. Glass eels were collected quantitatively in triangular scoop nets (mouth $0.3 \mathrm{~m}^{2}$. mesh $1 \mathrm{~mm}$ ) over a $10 \mathrm{~m}$ transect of beach at the mouth of the Poigar River, north Sulawesi Island, Indonesia, at $2 \mathrm{~h}$ intervals for a full day, at the new moon of each month of 1997 (Fig. 1). The glass eels sampled were fixed in $10 \%$ formalin immediately after collection, and the total number of specimens was counted. A 


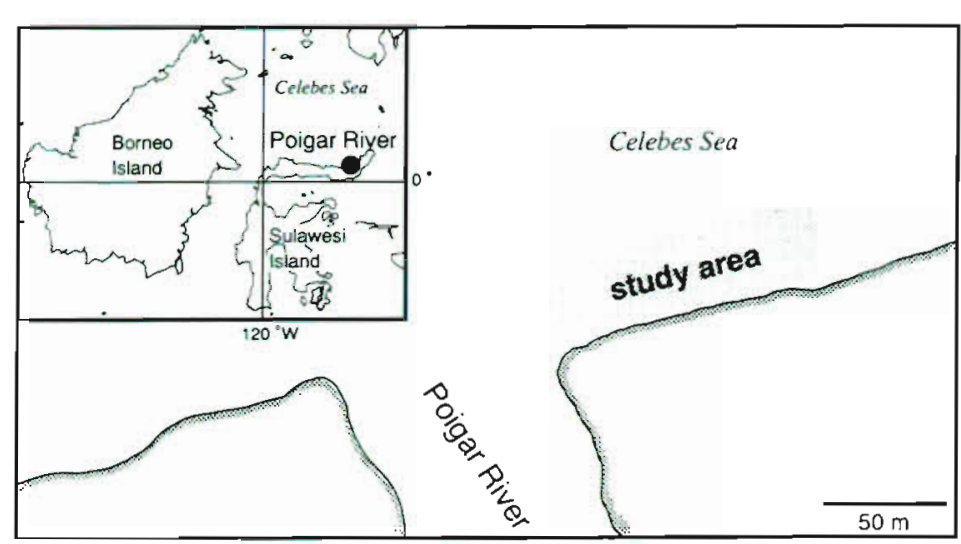

Fig. 1. Map showing the mouth of the Poigar River and the study area from which glass eels were collected

diethyl ether, then concentrated by ethanol precipitation. A portion of mitochondrial $16 \mathrm{~S}$ ribosomal RNA was amplified via polymerase chain reaction (PCR) using oligonucleotide primers, L1854 (Aoyama 1998) and H3058 (Miya \& Nishida 1996). Amplification parameters were 40 cycles of denaturation at $94^{\circ} \mathrm{C}$ for $30 \mathrm{~s}$, annealing at $50^{\circ} \mathrm{C}$ for $30 \mathrm{~s}$, and extension at $72^{\circ} \mathrm{C}$ for $60 \mathrm{~s}$. PCR products were processed by 2 restriction enzymes, Bsp1286I (Takara Shuzo Co., Ltd) and BbrPI (Toyobo Co., Ltd). Restriction procedures were carried out in a solution containing $5 \mu \mathrm{l}$ PCR product, 10 units restriction enzyme and $2 \mu$ restriction enzyme buffer (supplied by manufactures) for a final volume of $20 \mu \mathrm{l}$, which was incubated at $37^{\circ} \mathrm{C}$

total of 21633 specimens was collected during this year-long survey. Samples for genetic analysis (2 to 116 specimens each month) were also collected at night (20:00 to 02:00 h) just after each quantitative sampling, and were preserved in $99 \%$ ethanol immediately after collection.

In those months when only a few specimens (less than 30) were collected for mtDNA analysis (February, March, September and December), all specimens were examined (2 to 10 specimens), while during the other months (January, April to August, October and November), 30 specimens were randomly selected from each sample bottle, for a total of 272 glass eels examined genetically. The total length (TL) and predorsal, ano-dorsal and preanal lengths of the specimens were measured to the nearest $0.1 \mathrm{~mm}$, and the pigmentation stage was determined after Bertin (1956). Based on the ano-dorsal length as a percentage of TL (Ege 1939, Castle \& Williamson 1974, Tabeta et al. $1976 \mathrm{~b})$, the glass eels were first classified as either long-finned (6.0 to $18.9 \% ; 253$ specimens) or shortfinned eels (-6.0 to $3.9 \% ; 19$ specimens). According to Eqe (1939) and Castle \& Williamson (1974), 1 shortfinned eel, Anguilla bicolor pacifica, and 3 long-finned eels, A. celebesensis, A. marmorata and $A$. borneensis, are known to be distributed in the vicinity of north Sulawesi Island. We initially excluded $A$. bicolor pacifica by morphological examination. However, $A$. celebesensis and $A$. borneensis have been reported as being difficult to distinguish by their vertebral characteristics alone (Tabeta 1976b). We therefore carried out polymerase chain reaction-restriction fragment length polymorphism (PCR-RFLP) analysis, which has recently been established as a convenient tool for identifying members of the genus Anguilla (Aoyama 1998).

For long-finned eels (253 specimens), total genomic DNA was extracted once using phenol/chloroform/ isoamyl alcohol (25:24:1 vol/vol) and twice using overnight. Restricted fragments were detected by electrophoresis on $1 \%$ agarose gel, and by ethidium bromide staining. The fragment patterns obtained from all long-finned specimens were compared with previously established species-specific genotypes (Aoyama 1998).

We obtained the species composition in \% of specimens morphologically and genetically analyzed (272) and estimated the species composition of the main sample collected quantitatively every month.

Results. Glass eels were present in the Poigar Estuary throughout the course of the study (Fig. 2). The peak season of inshore migration was from May (4832 specimens) to June (13497 specimens). A few specimens were collected in February (29 specimens), March (22 specimens), September (19 specimens) and December (2 specimens) (Fig. 2). All specimens showed undeveloped pigmentation with only a few melanophores in the caudal region, or at the skull, caudal and rostral regions of the body (VA or VB).

The PCR-RFLP analysis carried out with Bsp1286I exhibited a single genotype (fragments of 920 and 370

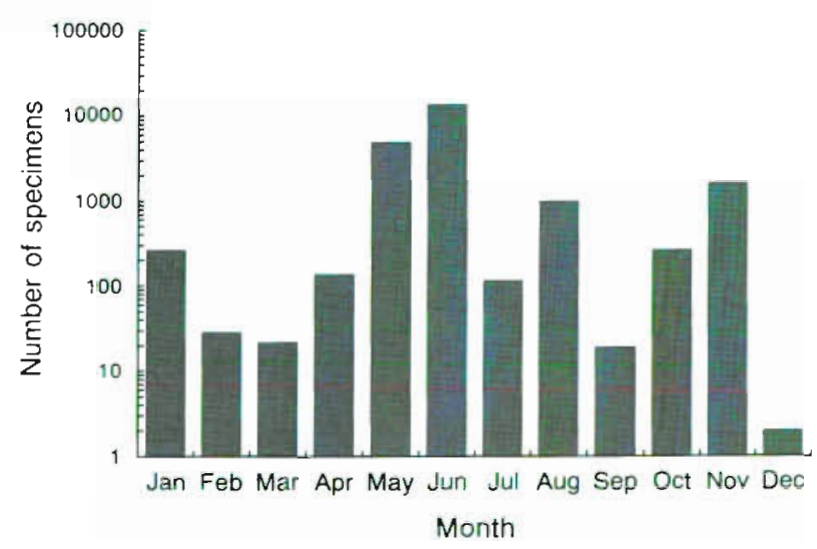

Fig. 2. Monthly catch of Anguilla spp. glass eels at the mouth of the Poigar River throughout 1997 


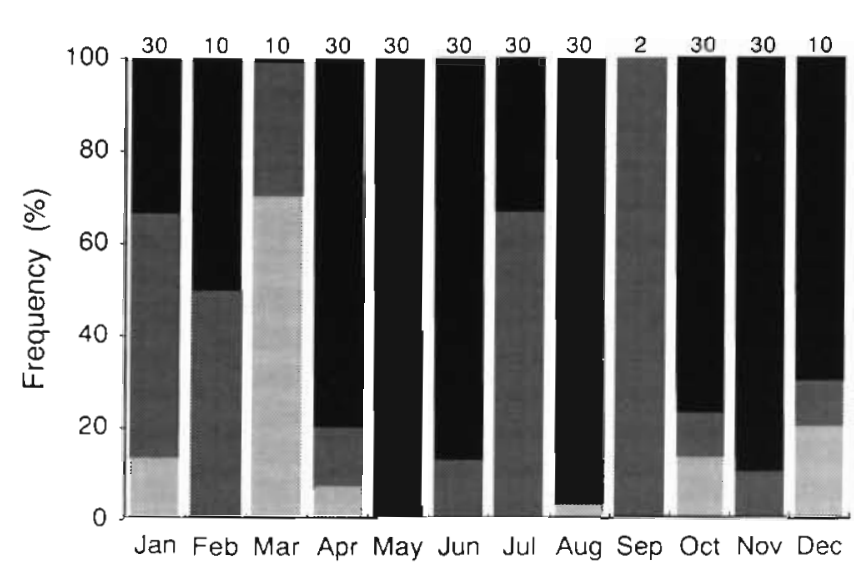

Month

Fig. 3. Frequency distribution of Anguilla celebesensis, A marmorata and $A$. bicolor pacifica, as revealed by both morphological characteristics and mtDNA analysis of 272 glass eels from monthly samples collected at the mouth of the Poigar River in 1997. Numbers at the top of each column indicate the number of specimens examined

base pairs in length were observed) that corresponded to an Anguilla celebesensis/A. marmorata species group-specific fragment pattern, while the genotype corresponding to the fragment pattern of $A$. borneensis (650, 370 and 300 base pairs long) was not found among the specimens examined here. The analysis by BbrPI clearly showed 2 genotypes (one with no restriction site and the other being 780 and 540 base pairs long). The former fragment pattern was reported as A. marmorata specific, and the latter as $A$. celebesensis (Aoyama 1998), and thus the examined specimens could be precisely distinguished as follows: 190 A. celebesensis, 63 A. marmorata, and 19 A. bicolor pacifica.

Seasonal changes in species composition of the glass eels revealed by mtDNA analysis are shown in Fig. 3. Anguilla celebesensis was the most dominant species $(69.9 \%)$, occurring almost throughout the year, except in March and September. A. marmorata was the second most dominant (23.1\%), and was seen throughout the year. A few A bicolor pacifica (7.0\%) occurred in January, March, April, October and December.

Based on glass eel abundance shown in Fig. 2 and species composition shown in Fig. 3, the number of inshore migrants was estimated for each species in each month (Fig. 4). Anguilla celebesensis represented a dominant $88.3 \%$ of all eel species seen, with a peak number of more than 10000 individuals as catch per unit effort (CPUE) in June. The number of A. marmorata $(11.3 \%)$ also peaked in June, with more than
1000 individuals as CPUE. In the case of $A$. bicolor pacifica, although the total number collected over the whole migration period did not exceed 100 individuals, peaks were observed in January and October.

Discussion. The species composition and seasonal occurrence of anguillid glass eels in the Poigar River, Sulawesi Island, were precisely determined in this study. Ege (1939) recognized 4 anguillid species in the Poigar River, i.e. Anguilla ancestralis, A. celebesensis, A. marmorata and A. bicolor pacifica. However, after
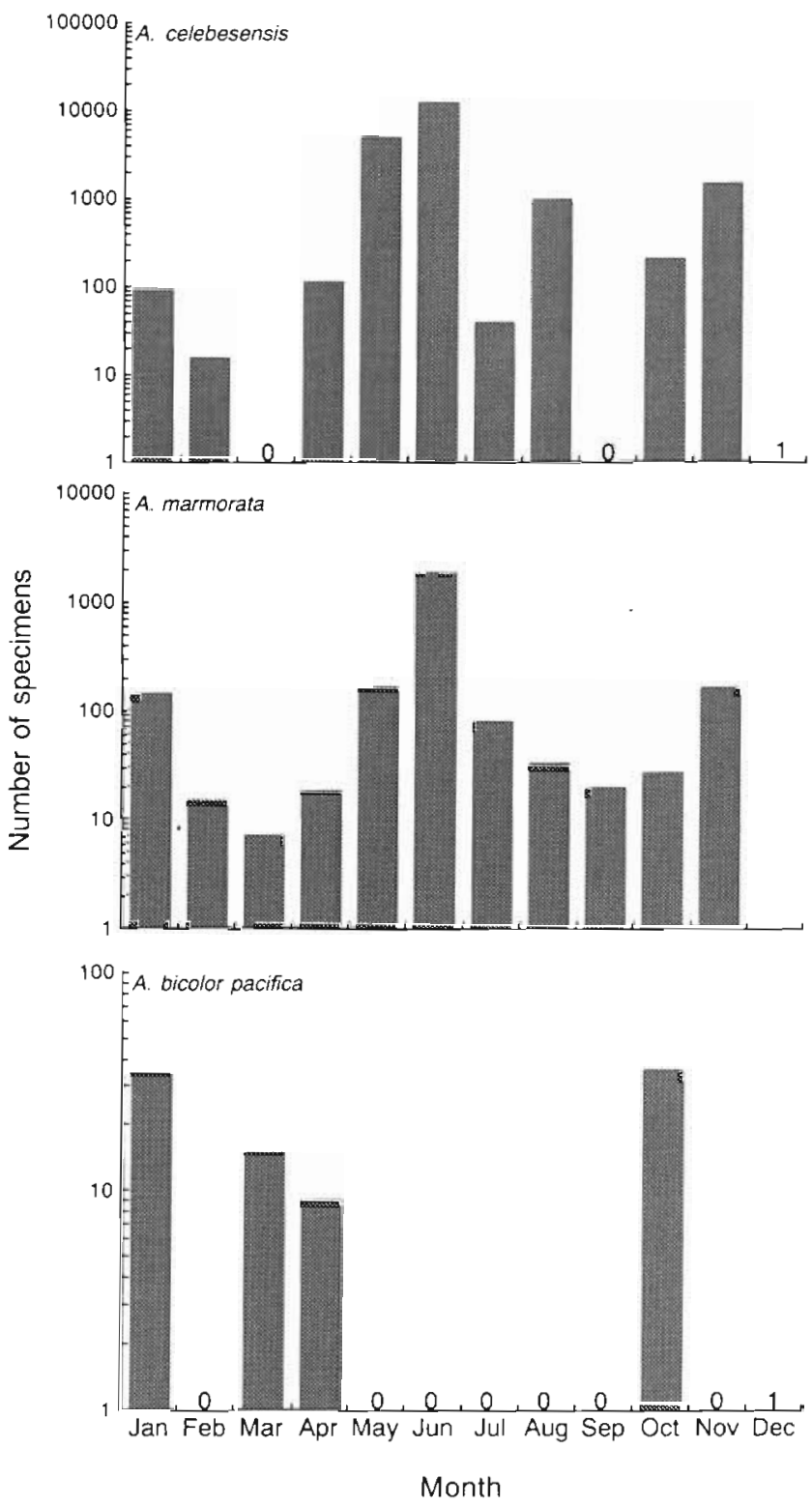

Fig. 4. Seasonal variations in the inshore migration of Anguilla celebesensis, A. marmorata and A. bicolor pacifica, as estimated by quantitative monthly collection of glass eels at the mouth of the Poigar River in 1997 
re-examination of Ege's sample, Castle \& Williamson (1974) proved that $A$. ancestralis should be regarded as A. celebesensis, because there was no valid means of distinguishing between the two. They also recognized A. borneensis based on 2 adults and 4 elver specimens, and thus reported a total of 4 Anguilla spp. in the Poigar River, i.e. A. celebesensis, A. marmorata, A. bicolor pacifica and $A$. borneensis. Tabeta et al. (1976b) suggested that it was difficult to distinguish between $A$. borneensis and $A$. celebesensis based on only the vertebral characteristics in the juvenile stage. We found no A. borneensis in the Poigar River, based on mtDNA analysis of our monthly samples for the year. Therefore, continuous investigation on species composition in the Poigar River will be needed to examine more specimens in different years, together with a re-examination of the $A$. borneensis specimens described by Castle $\&$ Williamson (1974).

In this study, glass eels were found to occur throughout the year. Tabeta et al. (1976a) also observed a similar occurrence of tropical anguillid elvers in the Cagayan River, Philippines. In the temperate species, however, inshore migration of juveniles occurs over a limited period, i.e. from winter to spring for Anguilla japonica (Matsui 1972), A. australis and A. dieffenbachi (Jellyman 1979) and A. rostrata (Martin 1995). The differences in inshore migration periods between tropical species and temperate species might be due to differences in their spawning periods, their migration route and ocean current systems, and early life history parameters such as timing of metamorphosis and age at recruitment. In temperate eels, it has been revealed that A. japonica spawns from April to November (Tsukamoto 1990), and migrates via steady oceanic currents (Tsukamoto 1992), taking about 5 to 6 mo to travel from the spawning area to estuarine habitats (Cheng \& Tzeng 1996, Arai et al. 1997). In tropical species, it has been suggested based on otolith microstructure analysis that $A$. celebesensis and $A$. marmoratä spawn throughout the year (Arai unpubl.). Otolith Sr:Ca ratio analyses using an X-ray electron microprobe have also suggested that metamorphosis likely begins 3 to 4 mo after hatching, and recruitment to the estuary at 4 to 5 mo of age (Arai et al. 1999a,b, Arai unpubl.). Furthermore, these 2 otolith life history parameters were found to be almost constant throughout the year (Arai unpubl.). Therefore, the inshore migration period in tropical species would extend throughout the year due to year-round spawning and stable larval transport, while that in the temperate species might occur over only a limited period due to a limited spawning season. However, leptocephalus collection and oceanic observation will be needed to obtain direct information on the spawning season and larval transport mechanisms in tropical anguillid eels.
Acknowledgements. This work was supported in part by Grants-in-Aid Nos. 07306022, 07556046, 08041139 and 08456094 from the Ministry of Education, Science, Sports and Culture, Japan; Research for the Future Program No. JSPSRFTF 97L00901 from the Japan Society for the Promotion of Science; Eel Research Foundation from Nobori-kai; Research Foundation from Touwa Shokuhin Shinkoukai. Partial support was also given in the form of a Research Fellowships of the Japan Society for the Promotion of Science for Young Sci entists to T.A.

\section{LITERATURE CITED}

Aoyama J (1998) Molecular phylogeny and evolution of the freshwater eels, genus Anguilla. PhD thesis, The University of Tokyo

Arai T, Otake T. Tsukamoto $K$ (1997) Drastic changes in otolith microstructure and microchemistry accompanying the onset of metamorphosis in the Japanese eel Anguilla japonica. Mar Ecol Prog Ser 161:17-22

Arai T, Otake T, Daniel L, Tsukamoto K (1999a) Early life history and recruitment of the tropical eel, Anguilla bicolor pacifica, as revealed by otolith microstructure and microchemistry, Mar Biol 133:319-326

Arai T, Daniel L, Otake T, Tsukamoto K (1999b) Metamorphosis and inshore migration of tropical eels, Anguilla spp., in the Indo-Pacific. Mar Ecol Prog Ser 182:283-293

Bertin L (1956) Eels - a biological study. Cleaver-Hume Press Ltd, London

Budimawan (1997) The early life history of the tropical eel Anguilla marmorata (Quoy \& Gaimard, 1824) from four Pacific estuaries, as revealed from otolith microstructural analysis. J Appl Ichthyol 13:57-62

Castle PHJ, Williamson GR (1974) On the validity of the freshwater eel species Anguilla ancestralis Ege from Celebes. Copeia 2:569-570

Cheng PW, Tzeng WN (1996) Timing of metamorphosis and estuarine arrival across the dispersal range of the Japanese eel Anguilla japonica. Mar Ecol Prog Ser 131:87-96

Deelder CL (1958) On the behavior of elvers (Anguilla vulgaris Turt.) migrating from the sea into fresh water. $J$ Cons Int Explor Mer 24:135-146

Ege V (1939) A revision of the genus Anguilla Shaw. Dana Rep 16(13):8-256

Gandolfi G, Pesaro M, Tongiorgi P (1984) Environmental factors affecting the ascent of elvers, Anguilla anguilla (L.). into the Arno River. Oebalia 10:17-35

Jellyman DJ (1977) Invasion of a New Zealand freshwater stream by glass eels of two Anguilla spp. NZ J Mar Freshw Res 11:193-209

Jellyman DJ (1979) Upstream migration of glass eels (Anguilla spp.) in the Waikato River. NZ J Mar Freshw Res 31:13-22

Lecomte-Finiger R (1992) Growth history and age at recruitment of European glass eels (Anguilla anguilla) as revealed by otolith microstructure. Mar Biol 114:205-210

Martin MH (1995) The effects of temperature, river flow, and tidal cycles on the onset of glass eel and elver migration into freshwater in the American eel. J Fish Biol 46: $891-902$

Matsui I (1952) Studies on the morphology, ecology and pondculture of the Japanese eel (Anguilla japonica Temminck \& Schlegel). J Shimonoseki Coll Fish 2:1-245

Matsui I (1972) Eel biology-biological study. KoseishaKoseikaku, Tokyo

Miya M, Nishida M (1996) Molecular phylagenetic perspec- 
tive on the evolution of the deep sea fish genus Cyclothone (Stomiiformes: Gonostomatidae). Ichthyol Res 43:375-398

Sloane RD (1984) Invasion and upstream migration by glass eels of Anguilla australis Richardson and A. reinhardti Steindachner in Tasmanian freshwater streams. Aut J Mar Freshw Res 35:47-59

Sorensen PW (1986) Origins of the freshwater attractant(s) of migrating elvers of the American eel Anguilla rostrata. Environ Biol Fishes 17:185-200

Tabeta O, Tanimoto T, Takai T, Matsui I, Imamura T (1976a) Seasonal occurrence of anguillid elvers in Cagayan River, Luzon Island, the Philippines. Bull Jpn Soc Scient Fish 42: $421-426$

Tabeta O. Takai T, Matsui I (1976b) The sectional counts of vertebrae in the anguillid elvers. Jpn J Ichthyol 22:195200

Tesch FW (1971) Aufenthalt der Glasaale (Anguilla anguilla)

Editorial responsibility: Otto Kinne (Editor),

Oldendorf/Luhe, Germany an der südlichen Nordseeküste vor dem Eindringen in das Süsswasser. Vie Milieu Suppl 22:381-392

Tongiorgi P, Tosi L, Balsamo M (1986) Thermal preferences in upstream migrating glass-eels of Anguilla anguilla. J Fish Biol 28:501-510

Tsukamoto K (1990) Recruitment mechanism of the eel, Anguilla japonica, to the Japanese coast. J Fish Biol 36: $659-671$

Tsukamoto K (1992) Discovery of the spawning area for the Japanese eel. Nature 356:789-791

Tzeng WN (1985) Inmigration timing and activity rhythms of the eel, Anguilla japonica, elvers in the estuary of northern Taiwan, with emphasis on environmental influences. Bull Jpn Soc Fish Oceanogr 47:11-28

Wang $\mathrm{CH}$, Tzeng WN (1998) Interpretation of geographic variation in size of American eel Anguilla rostrata elvers on the Atlantic coast of North America using their life history and otolith ageing. Mar Ecol Prog Ser 168:35-43

Submitted: February 2, 1999; Accepted: June 14, 1999

Proofs received from author(s): October 21, 1999 